\title{
«CRAS, CRAS». «VUELVA USTED MAÑANA»: GRACIÁN Y LARRA
}

Aurora EgIDo

RAE. Universidad de Zaragoza aegido@unizar.es

\section{RESUMEN}

En este artículo se analizan dos refranes, «cras, cras» y «vuelva usted mañana», en la obra de Baltasar Gracián y Mariano de Larra.

Palabras Clave: Paremiología, Gracián, Larra.

\section{AbSTRACT}

In this article we analyze two Spanish idioms, «Cras, cras» and «Vuelva usted mañana» («come back tomorrow»), in the works of Baltasar Gracián and Mariano de Larra.

KEY WORDS: Paremiology, Gracián, Larra.

En el laberinto ciudadano de El Criticón, lleno de seres viciosos, el jesuita aragonés menciona a los oficiales, que prometen y nunca dan, como ocurre con los sastres, pues

te dejan en cueros y las dan a cuervos, diciendo: Mañana señor, estará acabado, para mañana sin falta, ahora prosiguiendo en su misma canción van repitiendo, por castigo y por costumbre, aquel su icras, cras! que nunca llega. ${ }^{1}$

${ }^{1}$ Baltasar Gracián, El Criticón, ed. de Luis Sánchez Laílla e introducción de Aurora Egido, Madrid, BLU, 2001, p. 896. Recogimos la cita, en relación con el famoso «Vuelva usted mañana» de Mariano José de Larra, en La búsqueda de la inmortalidad en las obras de Baltasar Gracián, Discurso leído el 8 de junio de 2014 en la Real Academia Española, Madrid, 2014, e impreso, con tal motivo y en dicha fecha, por la Institución Fernando el Católico de Zaragoza. 
La cita remite inmediatamente al conocido «Vuelva usted mañana», de Mariano José de Larra, quien creemos pudo inspirarse en el jesuita aragonés a la hora de acuñar una actitud que, andando el tiempo, se convertiría en estereotipo de los españoles.

Pero antes de adentrarnos en tal parangón, no deja de ser curioso ese preterido «cras, cras» usado por Gracián y que está presente en algunos géneros que el propio jesuita alabó y utilizó en sus obras, incluido El Criticón $n^{2}$. Como señaló Cejador, el Siglo de Oro fue afecto a los refranes y frases de dilación, caso del «Acabara yo para mañana», «De aquí a mañana» $\mathrm{o}$ «Hablara yo para mañana, hablara yo para el tercio de la casa o para otro año», empleados irónicamente en el sentido «de lo que corre prisa y se trata con harto espacio, como quien dice: ¡Acabáramos! ¡Haberlo dicho antes!» ${ }^{3}$. Por otro lado, en esa época las referencias al cuervo remitían aún al crastinar del mismo, como signo de lo que se deja para otro día y nunca llega ${ }^{4}$.

Conviene recordar también que el adverbio cras, mañana, para otro día, ausente en el Tesoro de Covarrubias, lo había incluido Gonzalo Argote de Molina en el «Índice de algunos vocablos antiguos que se hallan en este libro, para noticia de la lengua Castellana», colocado al final de la primera edición de El Conde Lucanor de don Juan Manuel (Sevilla, Hernando Díaz, 1575) ${ }^{5}$. El arcaísmo reapareció en la obra de Gracián como una perla en desuso que sin embargo apelaba, con plena vigencia en su tiempo, a una actitud moral que él denunció junto a otros muchos vicios cortesanos.

El Conde Lucanor ofreció al jesuita dos ejemplos de cras: el XXXV, «De lo que aconteció a un mancebo que casó con una mujer muy fuerte et muy brava», y el XLV, «De lo que contesció a un omne que se fizo amigo et vasallo del Diablo», donde se percibe claramente el sentido de dilación implicado por tal término: «Mas tengámoslo fasta cras et veremos más en este fecho, ca si culpado es, ý se finca para cumplir cras la justicia» ${ }^{6}$.

Cras formó parte del sistema de adverbios temporales que se acercan al propio de los sustantivos, y cuyo uso durante los siglos XIII a XVI fue descendiendo hasta su

\footnotetext{
${ }^{2}$ Corominas- Pascual documentan cras en Berceo, don Juan Manuel, el Poema de Alfonso XI, Sem Tob, el Rimado de Palacio y Nebrija, entre otros. También recogieron su presencia en El Criticón I, 229, anotado por Romera-Navarro (infra), y el artículo de Alfonso Reyes en RFE II, 383.

3 Véase Julio Cejador y Frauca, Diccionario fraseológico del Siglo de oro (Fraseología o estilística castellana), ed. de Abraham Madroñal y Delfín Carbonell, Barcelona, Serbal, 2008, con referencias a La Pícara Justina y al Quijote, 1, 19. «Mañana ayunará Gálvez», remitía a quien lo deja todo para mañana.

${ }_{4}$ «Cras crastinando, dijo el cuervo, y no sé cuándo se tornará blanco. (Contra los que dilatan lo que han de hacer. Estudiantes dicen cras crastinando nescio quando, en latín)», según Cejador, quien también se refiere a «enviar al cuervo, contra el criado y mensajero que tarda y no vuelve». Véase además Sebastián de Horozo, Tratado universal de proverbios, ed, de José Luis Alonso Hernández, Universidad de Salamanca, 2005, p. 898, donde recoge dicho refrán en Gonzalo Correas, Vocabulario de refranes y frases proverbiales (1627), ed. de L. Combet, R. Jammes y M. T, Mir, Madrid, Castalia, 2000, nn. 1113 y 1329: «Contra los que dilatan lo que han de hacer». Y véase Jesús Cantera Ortiz de Urbina, Refranero latino, Madrid, Akal, 2005, p. 48: «Cras crastinando, preterit diez et nescis quando» (Vallés, Latino 25) y «Per multum cras, cras crebo dilatabitur aetas». A su vez María Moliner recoge el «Mañana será otro día. Expresión informal con que se deja o difiere algo para el día siguiente».

5 Sobre ello, véase por extenso el artículo de José Romera Castillo, «El Conde Lucanor y la lengua del siglo XVI», Anuario de Letras 19, 1981, pp. 271-291. Covarrubias recogió sin embargo las frases relativas a «mañana» que aludían a la susodicha dilación, como recordó el propio Cejador en su mencionado Diccionario.

${ }^{6}$ Don Juan Manuel, El Conde Lucanor, ed. de Guillermo Serés, estudio preliminar de Germán Orduna, Barcelona, Galaxia Gutenberg, 2008, pp. 151 y 186.
} 
desaparición en el XVII ${ }^{7}$. Gracián retomó su sentido onomatopéyico y añejo, remitiendo a una tradición literaria que lo había utilizado en contextos didácticos afines al suyo, incluidos los refranes, las fábulas y las máximas, que venían cargados de filosofía moral ${ }^{8}$.

No deja de ser curioso, en este sentido, que, en la pugna entre cras y mañana, Gracián se resolviera por incluir ambas voces en el mencionado ejemplo, como homenaje a toda una vieja tradición que él rescató en su obra magna, tratando de modernizarla.

La presencia de la literatura medieval en las obras del jesuita aragonés, particularmente en la Agudeza, es bien conocida por la crítica, que ha destacado particularmente su devoción por El Conde Lucanor, que Gracián consideró digno de formar parte de la librería délfica9 ${ }^{9}$. Dicha huella ha sido señalada como fuente de las agudezas paradójicas, las crisis irrisorias y los conceptos por ficción emanados de la obra del príncipe don Juan Manuel, al que consideraba un auténtico exponente de la «moral filosofía» ${ }^{10}$.

Cristina Orobitg señaló precisamente las susodichas concomitancias de Gracián con la versión truncada de El Conde Lucanor de Argote de Molina, ya subrayadas anteriormente por José Romera Castillo, recogiendo a su vez las alabanzas que vertió en la Agudeza y otras obras sobre don Juan Manuel, al que consideró maestro de la agudeza fingida y de la inventiva, aunque la posición adoptada en El Criticón fuera de sesgo

${ }^{7}$ Consúltese por extenso el estudio y la bibliografía recogida por María Elena Azofra Sierra, «Deixis adverbial temporal en la historia del español», Anuario de lingüística hispánica, XXV, 2009, pp. 15-34, con variedad de ejemplos. La autora señala cómo el adverbio mañana (de maneana, hora maneana o temprana en latín clásico) sustituye al medieval cras, como ya señalara Meyer-Lübke. También se refiere a su comportamiento sintáctico, cercano al propio de los sustantivos, según Alarcos y Bosque. Pertenece, según distintos criterios, a los adverbios léxicos de tiempo o deícticos, también llamados demostrativos, pronominales, identificativos, etc. Y véase la tesis doctoral de Carlos E. Sánchez Lencis, Estudio de los adverbios de espacio y tiempo en el Español medieval, dirigida por José Manuel Blecua Perdices, Barcelona, Universidad Autónoma de Barcelona, 1990.

${ }^{8}$ María Elena Azofra, Ib., p. 21, donde destaca su uso didáctico. La autora recoge ejemplos de cras en el Cantar de Mio Cid, los Milagros de Berceo, El Conde Lucanor y otras obras, remitiendo al descenso de su uso a partir de las estadísticas aportadas por el CORDE (infra). A su juicio, «En la transferencia del contenido semántico de cras a mañana muy probablemente influyó la frecuente asociación cras, mañana, con sus variante cras, en la mañana, y cras, de buena mañana». Parece un rasgo estilístico del Arcipreste de Hita y de Berceo. Autoridades lo consideró ya un arcaísmo. También hemos consultado la tesis doctoral de Antonia María Coello Mesa, «Morfología y sintaxis en el castellano del siglo XIV: El Conde Lucanor», Universidad de La Laguna, 2001, pp. 402ss., a propósito del adverbio de tiempo cras, que ya en 1500 se convierte en arcaísmo según el DCECH (Ib., p. 411).

9 Benito Pelegrin, «Gracián, admirateur pirate de don Juan Manuel», Bulletin Hispanique 90, 1988, 1-2, pp. 197-214. Y véase Antonio Pérez Lasheras, «La literatura española en la Agudeza de Gracián», Bulletin Hispanique, 109-2, 2007, pp. 545-587. Baltasar Gracián, Agudeza y arte de ingenio, ed. de Evaristo Correa Calderón, Madrid, Castalia, 1969, vol. I, p. 233, califica a don Juan Manuel de prudente y sazonado, además de maestro sagaz de filosofía moral. Otras referencias al mismo a partir de la obra de Argote, en I, p.276. Y véanse además los ejemplos de I, pp. 206-7; y II, pp. 77-8 y 197.

${ }^{10}$ Baltasar Gracián, Agudeza y arte de ingenio, I, p. 233 y II, 210. Téngase en cuenta que en I, p. 233, el belmontino confiesa claramente que el libro de El Conde Lucanor lo había ilustrado con notas y advertencias Gonzalo Argote de Molina, que lo había impreso modernamente, considerando era «varón insigne en noticias, erudición, historia y de profundo ingenio». Gracián recogió varios ejemplos del libro, encomiando la obra de don Juan Manuel como modelo de agudeza compuesta fingida. Gracián copió por extenso varios ejemplos, al igual que hiciera con los del Guzmán de Alfarache, considerando que además formaban parte de esa agudeza compuesta que él recrearía más tarde en El Criticón. Con ello trató de imitar la moralidad, la valentía en el empeño y la ingeniosa y pronta salida, que admiraba, por ejemplo, en el cuento de don Illán de Toledo, también asunto de futuras renovaciones literarias por parte de Borges. 
muy distinto ${ }^{11}$. Su presencia en el «Museo del Discreto» planteaba además el debate fundamental entre delectare et prodesse que la mencionada obra acarreara, tratando de fundirlos en un mismo horizonte de expectación ${ }^{12}$.

La historia de las formas breves, como cadena formal y temática, está por estudiar en toda su anchura, por lo que se refiere a la literatura española. En ella, son eslabones fundamentales los que engranan El Conde Lucanor con la obra de Gracián, así como los que van de este al ya mencionado Jorge Luis Borges, pasando incluso por los artículos de Mariano José de Larra, heredero de una tradición didáctica que abrió camino a un género periodístico de ejemplos señeros como el de Azorín, tan buen lector del belmontino.

Antonio Carreira ya analizó con perspicacia, a propósito de la corneja siniestra de Garcilaso, los vestigios literarios de los graznidos del cuervo al crocitar o crascitar, como anotaba Autoridades, «porque siempre parece que dicen cras» ${ }^{13}$. Los diversos ejemplos por él acarreados son una constatación de hasta qué punto las voces encadenan conceptos e ideas que se transmiten con distintas variantes a lo largo de los siglos. Y, en este caso, el «cras» del cuervo muestra bien a las claras cómo este fue signo de emplazamiento y dilación en numerosos autores, hasta llegar al famoso cuento de Edgard Allan Poe, The Raven (1845), donde cristalizó ese mañana que nunca llega en la conocida respuesta: «Nevermore». Lope de Vega en El piadoso aragonés (1626) lo había explicado meridianamente:

No hay cosa más inhumana

sirviendo, y de más rigor,

que ver un cuervo, señor,

diciendo siempre mañana ${ }^{14}$.

Sin entrar en los procelosos motivos del cuervo, confundido por los comentaristas de la Biblia con los prudentes doctores de la iglesia que iniciaban a sus discípulos en los

${ }^{11}$ Christine Orobitg, «Gracián, lector de don Juan Manuel a través de Argote de Molina», Criticón 56, 1992, pp. 117- 133. Y véase además Alberto Blecua, La transmisión textual de «El Conde Lucanor», Barcelona, Universidad Autónoma de Barcelona, 1980.

${ }^{12}$ Según Christine Orobitg, $I b$., «el estilo no es para Gracián una forma en el sentido de pura envoltura externa, sino la esencia misma de una escritura, su aliento»; perspectiva aristotélica del jesuita que convertía El Conde Lucanor en «reconocimiento de sí mismo», p. 125. Y véase también Luis Galván, «Horizontes de lectura en el ejemplo XI de El Conde Lucanor», RFE, LXXXIV, 2º 2004, 285-345. Sobre la unión de fondo y forma en toda la obra de Gracián, nuestro estudio mencionado en nota 1 y los recogidos en Bodas de Arte e Ingenio. Estudios sobre Baltasar Gracián, Barcelona, Acantilado, 2014.

13 Antonio Carreira, «Un retruécano en la primera Égloga de Garcilaso», Analecta Malacitana XX, 2, 1997, pp. 547-521, estudió los ejemplos de cras a propósito de la «siniestra corneja» garcilasista; ave que, como los grajos, pronunciaba también «cras» al graznar. Carreira remitía a Covarrubias, quien a su vez recogía el emblema 44 de Alciato In simulacrum spei, referido a la corneja que da buena esperanza porque dice «será» cuando no es, con voz confusa. También alude a otros ejemplos relativos al graznido de la corneja en el Quijote I, 14 y en las obras de Lope y otros autores. Y véase en particular Henry N. Bershas, «The use of cras in Golden Age Texts», Hispanic Review 40, 2, 1972, pp. 206-209.

${ }^{14}$ Antonio Carreira, $I b$. No olvidemos que en el emblema XLIV de Alciato sobre la imagen de la esperanza aparece la corneja, que, «fidelísima en los agüeros/ cuando puede decir que algo está bien/ dice que lo estará». Alciato, Emblemas, ed. de Santiago Sebastián, Aurora Egido y Pilar Pedraza, Madrid, Akal, 1985, p. 81. La imagen va vinculada a la caja de Pandora, que guarda la esperanza. Los comentaristas de Pinciano discutieron sobre si era la corneja o el cuervo la imagen representada por Alciato. Lo cierto es que ambas son aves que encarnaron la mencionada esperanza y los sueños vanos. Téngase en cuenta que el siguiente emblema de Alciato, «In diez meliora», apelaba a seguir adelante sin mirar atrás, como también dijo Gracián respecto a los pasos del ser humano. 
misterios sagrados, lo cierto es que, en su carrera simbólica, no faltó la identificación apolínea de semejante ave con la música y con la poesía ${ }^{15}$. En esa larga trayectoria, no faltan sin embargo atributos negativos homologables con los vicios, cuya negritud se compara a la de los cuervos, que desatienden a sus crías en el nido y no las reconocen hasta que cambian su blanco plumaje ${ }^{16}$. Tales connotaciones no acaban sin embargo ahí, pues, respecto al tema que nos ocupa, el símbolo más a propósito tal vez sea el del epigrama de Marcial «Ad Julium», que cristalizaría más tarde en el susodicho texto de Gracián, tan afecto a la obra del bilbilitano:

Non est, crede mihi, sapientis dicere «vivam».

Sera nimis vita est crastina: vive hodie ${ }^{17}$

Pues, en efecto, la connotación temporal de aplazamiento de algo que se deja para el día siguiente estaba ya claramente expresada en ese texto clásico, tal como Covarrubias lo explicó al pie de la pintura que mostraba un cuervo graznando sobre un árbol al sol poniente:

El cuervo dize cras, quando se pone

De Febo el carro por el Occidente;

Y quando a la mañana se dispone

A dorar con sus carros el Oriente

Repite el cras, y como siempre entone

Esta mesma palabra, eternamente,

Diciendo su bien de día en día,

El miserable muere en su porfía ${ }^{18}$.

La actitud postergadora del cuervo aparecía así, desde los clásicos, como ejemplo a contrario del conocido refrán «no dejes para mañana lo que puedas hacer hoy», por lo

15 José Luis García Arranz, Ornitología emblemática. Las aves en la literatura simbólica ilustrada en Europa durante los siglos XVI y XVII, Cáceres, Universidad de Extremadura, 1996, pp. 328-330. Abunda su carga simbólica y alegórica en los bestiarios y jeroglíficos, donde, partiendo de San Isidoro, se les concede ser atributo de la benignidad de Dios y de su providencia. Y véase Ib., pp. 331-2, sobre el ejemplo del cuervo en lo alto de un árbol que sostiene un trozo de carne en el pico mientras conversa con un zorro. La conocida fábula, presente en Esopo, Babrio y otros, llegó a El Conde Lucanor y al Libro de buen amor, y se convirtió en ejemplo clásico del que se deja seducir por los halagos. Otros símbolos del cuervo en relación con la vida monástica, como mensajero salido del arca de Noé, voraz, glotón y carnicero, en Sebastián de Covarrubias Horozco, Emblemas morales, Madrid, Luis Sánchez, 1610. Véase Antonio Bernat Vistarini y John Cull, Enciclopedia Akal de emblemas españoles, Madrid, Akal, 1999, n 506. El nº 507, de Diego López, lo dibuja comiendo un escorpión, que le causará la muerte, como ejemplo de la venganza justa: «que el que en mal anda, tal acaba».

${ }^{16}$ Enciclopedia Akal, $\mathrm{n}^{\circ} 509$.

${ }_{17}$ Enciclopedia Akal, $\mathrm{n}^{\circ}$ 508, donde se remite a Marcial 1. 15. «No es de sabios el decir/ 'Vida tengo, el gusto aguarde`,/ que para mañana es tarde/ y hoy solo se ha de vivir», es la traducción ofrecida por Marcial en verso castellano, ed. de Andrea Bresadola, Pavia, Ibis, 2008, p. 237. El mismo Marcial recogió el término en 5, 58, 1: «Cras te victurumm, cras dicis, Postume, semper/ Dic mihi, cras istud, Postume, quando venit?/ Quam longe cras istud, ubi est?», traducido por «Sola una esperanza vana/ Póstumo tus cosas trata/ y a mañana las dilata/¿cuándo vendrá esta mañana?», $I b$., p. 348. Véase además Gerónimo Martín Caro y Cejudo, Refranes y modos de hablar castellanos, con los latinos que les corresponden..., Madrid, Imprenta Real, 1792, p. 191, que lo relaciona con el refrán «Lo que has de hacer, no digas cras, sino pon la mano, y haz», mencionando también su presencia en Marcial.

${ }_{18}$ Enciclopedia Akal, p. 262, donde se remite a la Centuria 2, emblema 100, f. 200, de Covarrubias, con la clave: «No dejar nada para mañana». 
que acarreaba como símbolo de negligencia, preterición y aplazamiento, sin olvidar que lo era también de lengua garrula, parlera y chismosa ${ }^{19}$.

Bien conocido es el peso de la fábula en las obras de Gracián; un género de raigambre clásica y popular, que él utilizaría para sus propios fines, dándole particular relieve en El Discreto y sobre todo en El Criticón, donde aparece a propósito de Pitágoras, el susodicho cras, cras, de negras y tristes resonancias, del cuervo ${ }^{20}$.

Pero de sus numerosas plumas simbólicas, es evidente que el belmontino recogió aquellas que lo configuraron históricamente como encarnación misma de la dejadez y la postergación en su onomatopéyico cras cras. Recordemos, por otro lado, que el mismo Libro de buen amor ya lo mostraba así en el conocido planto del Arcipreste de Hita por Trotaconventos, donde este mostró los estragos de la muerte:

No se encontrará un libro, un escrito, una carta, hombre sabio ni necio que de ti bien departa; nada existe en el mundo que bien de ti se parta, excepto el cuervo negro que de ti, muerte, se harta;

Le dices cada día que pronto le hartarás como el hombre no sabe cuándo le matarás, si bien pudiere obrar, sea hoy; valdrá más que el esperarte a ti y a tu amigo cras-cras.

Señores, no queráis ser amigos del cuervo:

Temed sus amenazas y no cumpláis su ruego.

El bien que hacer pudiereis, hacedlo luego, luego,

Que moriréis mañana, pues la vida es un juego.

La salud y la vida muy rápida se muda,

$\mathrm{Y}$ en un punto se pierde: de esto no cabe duda; «el bien te haré mañana» es expresión desnuda:

Vestidla con las obras antes que muerte acuda ${ }^{21}$.

La extensa cita bien vale la pena, en la medida en que nos muestra hasta qué punto el crascitar del cuervo ejemplificaba a las mil maravillas toda una filosofía moral que lo identificaba con un vicio pernicioso que había que desterrar.

19 Enciclopedia Akal, $\mathrm{n}^{\mathrm{o}}$ 510, donde aparece como símbolo de los delatores infames. En CORDE se recogen varios emblemas de Garau y de Diego López con el cras cras, como ejemplo de dilación. En el $n^{\circ}$ 1293, se expresa el dicho: «El bien que oy pudieres fazer non lo guardes para cras», aparte muchos otros que alcanzan a dichos y refranes de Hernán Núñez, Nebrija, Juan de Valdés y un larguísimo etcétera.

${ }^{20}$ Véase nuestra introducción a Baltasar Gracián, El Discreto, Madrid, Alianza, 1997, y, en particular, María del Pilar Cuartero, «La fábula en Gracián», Baltasar Gracián. IV. Centenario. Actas del I Congreso Internacional «Baltasar Gracián: pensamiento y erudición, ed. de Aurora Egido, Fermín Gil Encabo y José Enrique Laplana, Zaragoza, Gobierno de Aragón-Institución Fernando el Católico-Instituto de Estudios Altoaragoneses, 2003, pp. 135-174.

${ }_{21}$ Juan Ruiz, Arcipreste de Hita, Libro de buen amor, ed. modernizada, estudio y notas de Nicasio Salvador Miguel, Madrid, Alhambra, 1984, p. 266. G. B. Gybbon Monypenny, en su ed. de Arcipreste de Hita, Libro de Buen Amor, Madrid, Castalia, 1988, pp. 146, 192 y 507, recoge otros ejemplos de cras. El correspondiente a la estrofa 507, muestra la relación que tiene el sastre que deja en cueros al cliente con el cuento del cuervo y el asno: «Allí están esperando quál avrá más rico tuero;/ non es muerto, ya dizen: ‘Pater noster`a mal agüero;/ como los cuervos al asno quando le desuellan el cuero:/ 'cras cras nós lo avremos, que nuestro es ya por fuero'». 
Perseguir la trayectoria léxica e incluso moral de cras, cras nos llevaría lejos, pues abundan los ejemplos de todo tipo, desde el Cantar de Mío Cid, las Siete Partidas, el Sendebar, el Cuento de Tristán de Leonís y el mencionado Conde Lucanor, al León prodigioso de Gómez de Tejada, donde se lee: «cuervos que hoy para comer os sacarán los ojos, y su cras es el cuidado qué comerán mañana» ${ }^{22}$. Aparte habría que considerar su presencia en los proverbios latinos, como el que dice «Cras, cras crastinando nunquam das», donde se repite el mismo esquema de aplazamiento relacionado con dicho cuervo $^{23}$.

Pero al margen del consolidado aplazamiento del «cras, cras», el supuesto por «para mañana» gozó también de cierta prevalencia en la fraseología áurea, como ya señaló Cejador, al recoger diversos ejemplos, entre los que no faltó uno sacado del Quijote I, 19: «Hablara yo para mañana» ${ }^{24}$.

Gracián sin embargo fue mucho más allá de esa tradición, fundamentalmente paremiológica, al insertar el motivo del cuervo en la crisi séptima de la Primera Parte de $E l$ Criticón, titulada «La fuente de los engaños». Su presencia no es, en ese caso, circunstancial, pues aparece junto a la denuncia de toda una panoplia de vicios cortesanos que se coronan con el de la mentira y que se acrisolan en todo tipo de oficios y personas.

Curiosamente el «cras, cras» graciano aparece relacionado con «las casas de oficiales», «gente contraria a los labradores que no saben mentir», y que él convierte en cuervos domésticos del laberinto ciudadano. El guía Proteo, utilizando un dicho atribuido a Pitágoras por Diógenes de Laercio sobre la transmigración de las almas, afirma que aquel convertía a los crueles en tigres, a los soberbios en leones y a los deshonestos en jabalíes, transformando en cuervos «las almas de los oficiales, especialmente aquellos que nos dejan en cueros, cuando nos visten», en clara alusión a los sastres. Tras mencionarlos, Gracián añadía a los términos de la ya citada frase lo siguiente: «y como siempre habrían mentido, diciendo mañana, señor, estará acabado, para mañana sin falta: ahora, prosiguiendo en su misma canción, van repitiendo por castigo y por costumbre aquel su cras, cras que nunca llega».

El hecho de que Andrenio visite en esa crisi el reino del Hacer parecer, verdadera arte de las artes, no parece baladí. Sobre todo teniendo en cuenta que pasan por «la calle del callar y ver para vivir», donde precisamente se sitúan las casas de los citados oficia$\operatorname{les}^{25}$. Evidentemente la referencia a los sastres no deja lugar a dudas respecto a quienes,

${ }^{22}$ Son algunos ejemplos de entre los más del millar registrados en el CORDE.

$23 \mathrm{Ib}$ e infra, nota 71 .

24 Julio Cejador y Frauca, Diccionario fraseológico del Siglo de Oro, ed.cit., donde apunta, a renglón seguido: «hablara yo para el tercio de la casa, o para otro año (Dícese al que ya tarde acabó de decir lo que quería, debería o querría)..., mostrando la ironía y admiración respecto a lo que corre prisa y se trata con harto espacio». También recoge un «Mañana, mañana; pásase el tiempo y no hacemos nada».

${ }_{25}$ Miguel Romera Navarro, en su ed. de Baltasar Gracián, El Criticón, Philadelphia-London, Universidad de Pennsylvania-Oxford University Press, 1938, I, p. 229, anota «oficiales», como «persona que trabaja en un oficio» y remite a la atribución del mencionado dicho de Pitágoras a Diógenes de Laercio VIII, i, 14. Respecto a los sastres que dejan en cueros, recoge un ejemplo de Vélez de Guevara «a lo largo hilvanan los vestidos y a puñaladas los dueños», con otro de Villalón, donde habla de los hurtos de los sastres. Respecto a cras, menciona los precedentes del Cantar de Mio Cid, Fernán González y el Libro de Buen amor. En la edición preparada por José Enrique Laplana, María del Pilar Cuartero y Luis Sánchez Laílla con la colaboración de Sagrario López Poza, de Baltasar Gracián, El Criticón, Zaragoza, Institución Fernando el Católico, se añadirán otros precedentes al respecto, como el relativo al Guzmán de Alfarache, II, i, 7; referencia que agradezco. Pensemos 
además del vicio de dejarte en cueros, emplazan el término de su labor para mañana mintiendo descaradamente ${ }^{26}$.

En ese contexto, resulta plausible que Mariano José de Larra se inspirase en $E l$ Criticón a la hora de construir su famoso artículo «Vuelva usted mañana», pues, aunque desterrase de su léxico el añejo «cras, cras», lo cierto es que el aplazamiento del «mañana» guarda no pocas concomitancias con la obra del jesuita. Me refiero sobre todo a la presencia de los «oficiales» en su artículo, habida cuenta de que Gracián no sólo los nombra, sino que destaca la palabra en el margen del libro, como tantas otras que conforman un índice mnemotécnico a tener en cuenta por el lector en las dos primeras partes de su obra.

El término oficial no sólo remite a oficios manuales, como el de los sastres, en $E l$ Criticón, sino que apela a una serie de funciones y hasta de lo que hoy entendemos por funcionarios, entre los que se encuentran los maquiavelistas, que engañan al auditorio con verdades «de establo» en la farsa diaria representada en el teatro de todo el mundo. ${ }^{27}$ $\mathrm{Si}$ a ello añadimos que en esa misma crisi engañosa aparece un hombrecillo desarrapado que es extranjero al que un gran cortesano lleva a su casa, dándole la bienvenida y haciéndose el amigo para luego engañarle, las concomitancias con el ejemplo acarreado por El Pobrecito hablador se agrandan más aún si cabe.

El jesuita aragonés dice además que ese «necio extranjero» «se fía de todos y todos le engañan», identificándolo como un desdichado que representa a la humanidad entera («hombre de todos, y todos somos él»), considerando además que el primer embustero es el mismo Mundo, «que ofrece mucho y nunca cumple». Gracián inserta así la parábola de las mentiras del cuervo en el amplísimo campo de las desgracias humanas, y dentro de un mundo aciago en el que todos se burlan del hombre miserable, que «hoy es polvo, y mañana nada ${ }^{28}$. Critilo terminará además harto, «enfadado de tanto “ $i$ Sin falta!" con tantos», lo que extiende el vicio del prometer y nunca dar a un amplísimo espectro mundano que va más allá de los sastres.

Pasados casi dos siglos, el artículo de Larra se apartó del sentido paremiológico del cras, cras, olvidando la secular fábula del cuervo y la carga de filosofía moral que se desprendía de la crisi graciana para andar por otros derroteros. Lo que en El Criticón

en la importancia de esta obra en la Agudeza y sobre todo en El Criticón, que tanto debe a su admirado Mateo Alemán, extremo intermedio entre El Conde Lucanor y la obra de Gracián digno de consideración respecto al tema que nos ocupa.

${ }^{26}$ Romera Navarro, Ib., comenta el cras, cras añadiendo refranes, como el «de cras, en cras, vase el triste a Satanás, por el pecador que, aguadando al día de mañana para reformarse, acaba por morir impenitente». También remite a la Crónica de don Francesillo de Zúñiga:» ¡Quien volverse quisiere, tome el camino; que hoy haremos lo que cras no podremos». Pero esa y otra cita de la Miscelánea de Zapata («...mucho me aprietas y cras me besarás la mano»), tienen evidentemente otras connotaciones. El asunto de la preterición marcada por ese adverbio, ya se trate de cras o de mañana, no está lejos, por otro lado, de la filosofía de El Burlador de Sevilla de Tirso, que vive en un sempiterno «tan largo me lo fiáis».

${ }^{27}$ Cejador, opus cit., recoge «oficial de obra prima, consumado; en particular el zapatero excelente», aludiendo a «El oficio del perezoso» y entendiendo que los oficiales lo son de cualquier oficio manual, incluido el propio Dios, que hizo el mundo.

${ }^{28}$ Para el pecado de la mentira, véase Aurora Egido, «Multum in parvo, sobre las quintillas de Fray Luis de León “Aquí la envidia y mentira”», Aurea Poesis. Estudios para Begoña López Bueno, ed. de L. Gómez Canseco, juan Montero y Pedro Ruiz, Sevilla, Universidad de Córdoba, Universidad de Huelva, Universidad de Sevilla, 2014, pp. 163-181. 
suponía la formalización satírica y moral de un vicio cortesano ya denunciado por los clásicos y por la literatura popular, en Larra terminaba por convertirse en la denuncia de un vicio nacional, la pereza, que, unida a la mentira, alejaba a España del progreso que sin embargo existía en otros países europeos. El hecho de que fuera un francés, como Monsieur Sans-délai, con nombre simbólico, al igual que tantos otros de los que Gracián compuso, no debe desestimarse, aunque Larra se alejara totalmente de la alegoría para discurrir por el camino de la literalidad, demostrando que esta podía ser significativa y simbólica sin necesidad de dobles y hasta anagógicos sentidos ${ }^{29}$.

En ese aspecto, el ejemplo de la evolución del «cras, cras» al «vuelva Vd. mañana», es una buena expresión de la evolución misma de la propia literatura, que, desde los epigramas, refranes y cuentos cargados de lecciones morales, fue transformándose y acomodándose a los distintos géneros ofreciendo continuas novedades. En esa cadena de eslabones, la conseja del cuervo y su dilatado crascitar, dejó paso a un escueto «mañana, mañana», que lo decía todo por sí mismo.

Respecto al artículo de Larra, recordemos que el personaje de Sans-délai venía a España a solventar algunos asuntos de urgencia, y que, ya en sus primeras incursiones para hacer consultas en un genealogista, recibió por cuatro veces consecutivas la repuesta de «Vuelva usted mañana», que luego se repetiría en otras muchas diligencias igualmente aplazadas.

Larra no sólo encarnó a la pereza, y por consiguiente a su hermana la mentira, en la figura del sastre, a la que hacía referencia Gracián, sino en la de otros muchos oficios, como los de genealogista, traductor, escribiente, zapatero, planchadora y sombrerero. Pero también la extendió a otros conocidos y amigos que practicaban lo que hoy podríamos calificar de idéntico deporte. El narrador de «Vuelva Vd. Mañana» se refirió además, con particular insistencia, al «oficial de la mesa» de un ramo que no cita, pero que enseguida entendemos «oficializa», en sentido moderno, la pereza supuesta en el ámbito de la administración y la jurisprudencia, toda vez que se alude a un expediente que pasó a informe y que este pertenecía a «una tramitación legal...», que se dormía sin la diligencia debida y, por añadidura, envuelto en intrigas ${ }^{30}$.

Larra desdeñó las profundidades morales, pero agrandó en cierto modo y nacionalizó el ámbito de los oficiales al denunciar un vicio que además llevaba en la entraña el orgullo patrio y el desprecio por el extranjero y lo extranjero, ya denunciados a su manera por el propio jesuita ${ }^{31}$. Por otro lado, no deja de ser curioso que también coincidan ambos

${ }^{29}$ Mariano José de Larra publicó el artículo «Vuelva Vd. Mañana» con el seudónimo del Bachiller don Juan Pérez de Murguía en El Pobrecito hablador, nº 11, enero de 1833, pp. 1ss. Véase la ed. de Enrique Rubio, Mariano José de Larra, Artículos, Madrid, Cátedra, 1982, pp. 109-202.

${ }^{30}$ El DRAE habla del adjetivo oficial «que es del oficio, o sea que tiene autenticidad y emana de la autoridad derivada del Estado, y no particular o privado. Documento noticioso oficial». También señala al que trabaja o es empleado de una oficina, pero señala sobre todo al oficial de la sala, escribano en las causas criminales, cercano al uso que aparece en El Pobrecito hablador, con esa connotación de empleado en la administración del Estado que ya tiene en Larra y que no estaba en Baltasar Gracián.

${ }^{31}$ El término oficiales es para el jesuita remitente de cualquier oficio manual. El ya mencionado CORDE recoge 1453 ejemplos, cuya lectura lleva a considerar la connotación relativa a un oficio o a un cuerpo estatal, pues va unida a la mención de ordenanzas, sin que falte al respecto el uso, por parte de Clarín, en relación con el cuervo. Ese significado de oficial lo va adquiriendo en los siglos XVIII y XIX, tal y como hoy la reconocemos. En CORDE no faltan al reclamo los emblemas de Garau, Diego López, etc. 
autores en la alusión a los invisibles y a lo invisible, que tanto espacio ocupan en la sátira menipea de El Criticón, y que en Larra se concretan en la denuncia de lo dilatorio: «La mayor parte de nuestras cosas ¿o casos? No se ven». Recordemos también lo que les sucedía a él y a su amigo francés insistentemente: «Vuelva usted mañana —nos decían en todas partes-, porque hoy no se ve...», hasta que la historia acaba cuando, después de medio año largo, el informe solicitado por el extranjero no aparece, y este se va a su tierra tan cansado del «mañana eternamente futuro», como el otrora harto Critilo de Baltasar Gracián.

La nacionalización de la pereza por parte de Larra la convirtió, como dijimos, en estereotipo de los españoles, mezclándola con otros vicios, al igual que había hecho el jesuita en El Criticón. Pero aquél la dibujó ya no como un asunto de filosofía moral, sino como un pecado de negligencia, desidia y atraso que convenía remediar para estar a la altura de otros países de Europa. Larra, en definitiva, planteaba además la cuestión desde un punto de vista económico y hasta político, pues se refería a los extranjeros que vienen a España a invertir y sin embargo se encuentran con las puertas cerradas, volviendo desesperados a sus países sin resultado alguno por falta de diligencia y apoyo, escuchando ese «mañana» eternamente futurible.

Larra modernizó el viejo cras, cras de las consejas medievales, acarreando del acervo graciano, cargado de filosofía universal, una visión del perezoso y mortecino mundo cortesano que todavía estaba vigente en su época. Pero al convertir el «mañana, mañana» del cuervo en un vicio nacional, lo desprendió, según hemos visto, de su carga fabulística y simbólica para acrisolar, como si fuera algo nuevo, un «Vuelva Vd. Mañana» que le pertenecería para siempre. En este caso, y salvadas las distancias, al igual que ocurre con La vida es sueño o el El gran teatro del mundo, los precedentes del motivo eran numerosísimos, pero Larra, al igual que Calderón, lo convirtió en título y norte de un reclamo que terminaría siendo reconocido como exclusivamente suyo.

El siglo XIX no sólo inventó desde fuera los estereotipos nacionales a la zaga de una España tan romántica como atrasada, sino que los acrisoló lamentablemente desde dentro. Pero más allá de la verdad histórica de los mismos y de las pruebas que pudieran alegarse respecto a ello, lo cierto es que la tradición literaria contaba, y mucho, a la hora de configurarlos. Y el «vuelva usted mañana», tenía detrás una larga historia tan añeja como el simbólico «cras, cras» emitido por el cuervo, del que procedía secularmente.

El artículo de Larra se replegó a un vicio patrio, modernizando la filosofía moral que conllevara el esquema de ese falso «mañana, para mañana sin falta» presupuesto por Baltasar Gracián. Este sin embargo volvió más tarde al ámbito universal de las fábulas animales al que perteneciera, gracias al «Nevermore» representado por «El cuervo» de Edgar Allan Poe, demostrando una vez más que la literatura vive de las transformaciones, aunque no sean las falsamente atribuidas a Pitágoras, de las que se reía el jesuita aragonés.

Claro que la mayor y más constatada dilación tal vez sea aquella que es precisamente patrimonio de la literatura desde Las mil y una noches. Baltasar Gracián sabía mucho de ello, al dejar en suspenso el final de El Criticón a merced de los lectores, que debían continuar por sí mismos la obra que tenían en sus manos. Mariano José de Larra, a su vez, plantearía el asunto en «Vuelva Vd. mañana» a los que leyeran su artículo. Pues, al atribuirse a sí mismo el vicio de la pereza a la hora de escribir, que él denunciaba en sus 
paisanos, transformó el sintagma moral en paradigma estético de la escritura, convertida en el cuento de nunca acabar, gracias precisamente a la debida diligencia de los autores que la tienen por oficio ${ }^{32}$. La obligación de estos, en definitiva, consiste en alcanzar que su obra suponga un «pensar anticipado», que dure, como decía Baltasar Gracián en el Oráculo, «de hoy para mañana y aún para muchos días».

${ }^{32}$ En el prólogo del Quijote de 1605, «oficiales» se utilizó ya, aparte de «como del oficio», en el sentido de «amigos del oficio», aludiendo a aquellos amigos escritores que podrían haber enriquecido con sus alabanzas los preliminares del libro, de habérselo pedido Cervantes. Véase la ed. de Francisco Rico y Joaquín Forradellas, Barcelona, Instituto Cervantes-Ed. Crítica, 1998, p. 12, nota 37. 
